\title{
KARAKTERISTIK TEPUNG CAMPOLAY (Pouteria campechiana) UNTUK BISKUIT DENGAN VARIASI TINGKAT KEMATANGAN DAN SUHU BLANSING
}

\author{
Ela Turmala Sutrisno \\ Dede Zainal Arief \\ Tanti Oktapiani \begin{abstract}
Indonesia
E-mail : elaturmala@unpas.ac.id
\end{abstract} \\ Program Studi Teknologi Pangan, Fakultas Teknik, Universitas Pasundan, Jl. Dr.Setiabudi No 93, Bandung, 40153,
}

\begin{abstract}
Abstrak
Tujuan dari penelitian ini adalah untuk mengetahui pengaruh tingkat kematangan buah campolay (mengkal dan matang) dan suhu blansing yang berbeda terhadap karakteristik tepung campolay untuk biskuit. Rancangan percobaan yang digunakan pada penelitian ini adalah pola faktorial 2 × 3 dalan Rancangan Acak Kelompok (RAK) dan ulangan yang dilakukan sebanyak empat kali, sehingga diperoleh 24 satuan percobaan. Faktor yang digunakan dalam penelitian adalah tingkat kematangan (mengkal dan matang) dan suhu blansing $\left(50^{\circ} \mathrm{C}, 60^{\circ} \mathrm{C}\right.$ dan $\left.70^{\circ} \mathrm{C}\right)$. Respon penelitian utama mencakup respon kimia yaitu kadar air, kadar pati, kadar gula reduksi, kadar lemak, kadar abu, kadar serat kasar. Respon fisik terdiri dari daya serap air, kelarutan tepung, dan swelling power, serta penentuan rendemen tepung. Berdasarkan hasil penelitian, tingkat kematangan buah campolay berpengaruh terhadap karakteristik tepung campolay yaitu pada kadar air, pati, gula reduksi, rendemen tepung dan kelarutan tepung. Suhu blansing buah campolay berpengaruh terhadap kadar air, pati, gula reduksi, abu, serat kasar, rendemen, daya serap air, kelarutan dan swelling power tepung campolay. Kadar lemak tidak dipengaruhi baik oleh tingkat kematangan maupun suhu blansing. Interaksi antara tingkat kematangan dan suhu blansing juga tidak berpengaruh terhadap karakteristik tepung campolay. Berdasarkan hasil penelitian diperoleh sampel terpilih yaitu pada kode sampel k1s3 (tingkat kematangan mengkal dan suhu blansing $70^{\circ} \mathrm{C}$ ) dengan hasil respon kimia meliputi kadar air sebesar 8,81\%, kadar gula 13,02\%, kadar pati 44,17\%, kadar abu 3,88\%, kadar lemak 0,51\%, kadar serat kasar 5,07\%. Hasil respon fisik meliputi rendemen tepung sebesar 26,19\%, kelarutan tepung 41,53\%, daya serap air sebesar 48,03\% dan swelling power 6,78 g/g. Berdasarkan hasil uji organoleptik biskuit tepung campolay sampel kode 172 (perbandingan tepung campolay dan tepung terigu 75 : 25) paling disukai dalam hal warna, kerenyahan dan rasa.
\end{abstract}

\begin{abstract}
The purpose of this research is to know the influence of maturity level of campolay fruit (mature and ripe) and different blanching temperature to campolay flour for biscuit characteristic. The experimental design used in this study is a $2 \times 3$ factorial pattern in Randomized Block Design (RAK) and replication performed four times, to obtain 24 units of experiments. Factors used in the study were maturity level (mature and ripe) and blanching temperature $\left(50^{\circ} \mathrm{C}, 60^{\circ} \mathrm{C}\right.$ and $70^{\circ} \mathrm{C}$ ). The main research responses include chemical response: moisture content, starch content, reducing sugar content, fat content, ash content, crude fiber content. Physical response consists of water absorption, flour solubility, and swelling power, and flour rendemen. Based on the results of research, the maturity level of campolay fruit has an effect on the campolay flour characteristic that is in water content, starch, reducing sugar, flour rendemen and flour solubility. Blanching temperature effect on water content, starch, reducing sugar, ash, crude fiber, yield, water absorption, solubility and swelling power of campolay flour. Fat levels are not affected either by maturity level or blanching temperature. The interaction between maturity level and blanching temperature also has no effect on the campolay flour characteristics.Based on the result of the research, the samples obtained are the sample code k1s3 (mature and blanching temperature $70^{\circ} \mathrm{C}$ ) with the result of chemical response include water content of $8.81 \%$, sugar content $13.02 \%$, starch content $44,17 \%$, ash $3,88 \%$, fat content $0.51 \%$, crude fiber content $5.07 \%$. Physical responses include flour rendemen $26.19 \%$, flour solubility $41.53 \%$, water absorption by $48.03 \%$ and swelling power $6.78 \mathrm{~g} / \mathrm{g}$. Based on organoleptic test results of campolay flour biscuits 172 code samples (comparations of campolay flour and wheat flour 75: 25) are most preferred in terms of color, crispness and taste.

Keywords: Alkesa, Campolay, Campoleh, Canistel, Sawo Mentega, Biscuit, Campolay Flour, Maturity Level, Blanching Temperature
\end{abstract}

\section{Pendahuluan}

Buah campolay sering disebut Sawo Mentega, Sawo Ubi, Alkesa, atau Kanistel. Nama buah ini merujuk pada nama kota di Meksiko "Campeche", dalam bahasa inggris buah ini disebut sebagai Canistel, Egg Fruit, atau Yellow Sapote. Melihat manfaat buah ini, di beberapa negara termasuk Indonesia di beberapa 
daerah mulai membudidayakan tanaman campolay (Rizky,2012).

Buah campolay memiliki kandungan gizi yang cukup lengkap seperti serat, zat tepung, mineral, kalsium, fosfor, karoten, thiamin, riboflavin, niasin, dan vitamin C. Dengan adanya kandungan ini membuat buah ini disebut sebagai pangan fungsional sehingga mulai banyak di budidaya (Warta, 2015).

Campolay memiliki prospek dan peluang yang cukup besar sebagai bahan baku industri pangan. Perkembangan pemanfaatannya dapat ditingkatkan dengan cara penerapan teknologi yang tepat. Pemanfaatan buah ini masih terbatas, pada saat ini campolay diolah menjadi sirup buah campolay.

Bila dilihat dari tekstur buahnya, daging buah campolay yang kaya gizi ini dapat dipakai sebagai bahan campuran es krim, susu kocok (milkshake) dan juga cocok dijadikan bahan baku selai atau dodol. Bentuk pengolahan campolay yang memiliki peluang untuk dikembangkan salah satunya adalah pengolahan tepung campolay.

Pertimbangan buah campolay untuk dijadikan tepung selain pada kurangnya pemanfaatan buah campolay juga dikarenakan buah campolay memiliki kandungan pati yang dapat dijadikan alternatif tepung lain dari sumber karbohidrat seperti tepung singkong, tepung ubi jalar atau tepung ganyong selain ditujukan untuk mensubtitusi tepung terigu. Pertimbangan lainnya yaitu karena bahan baku campolay yang memiliki kandungan gizi yang lengkap. Rasa dan aroma tepung yang akan dihasilkan juga menarik untuk diaplikasikan pada produk biskuit.

Produk tepung merupakan bahan padatan yang diperoleh dari proses penggilingan suatu bahan dalam bentuk butiran-butiran halus yang mengandung kadar air $10 \%$ sampai $13 \%$. Tepung dapat diperoleh dari hasil pertanian yang mengandung karbohidrat tinggi (Hafiz, 2008).

Pengolahan bahan pangan menjadi tepung menjadi salah satu cara dalam mengawetkan bahan pangan segar sehingga lebih tahan lama, mudah untuk dikemas, memudahkan dalam penyimpanan dan pendistribusian, serta dapat digunakan untuk berbagai keperluan pengolahan sebagai bahan campuran cake, brownies, kue talam, biskuit atau kue kering (Adi, 2016).

Pada olahan diatas, bahan baku utama yang digunakan umumnya adalah tepung terigu. Perbedaan kandungan zat gizi yang mendasar pada tepung campolay adalah tidak mengandung zat gluten, yaitu zat yang hanya ada pada terigu yang menentukan kekenyalan makanan. Oleh karena itu perlu diperhatikan persentase penggunaan tepung campolay untuk mensubstitusi terigu disesuaikan dengan jenis produknya, sehingga tidak merubah kualitas produk, atau dapat dengan mensubtitusikan seluruh terigu dengan tepung campolay dan penambahan bahan pendukung lain yang dapat mempertahankan kualitas produk.

Pematangan merupakan proses perubahan susunan yang terjadi dari tingkat akhir pertumbuhan dan perkembangan yang terus-menerus akan menyebabkan kelayuan dan menentukan kualitas, yang ditandai dengan perubahan komposisi, warna, tekstur, dan sifat sensorik lainnya. Salah satu komposisi utama dalam buah adalah kandungan gula. Semakin matang buah maka kandungan gula buah semakin tinggi, hal ini sesuai dengan pernyataan Novita (2000) bahwa pada saat buah mulai matang kadar gula akan meningkat akibat terjadinya hidrolisis polisakarida menjadi gula.

Buah yang akan dikeringkan atau akan dibuat tepung umumnya diberi perlakuan pendahuluan berupa blansing sebelum pengeringan untuk meminimalisir reaksi pencoklatan pada buah. Menurut Muchtadi, dkk. (2013) blansing pada bahan pangan yang akan dikeringkan juga akan mempercepat proses pengeringan karena membuat membran sel permeabel terhadap perpindahan air.

Blansing dapat menyebabkan perubahan fisik dan kimia yang mengakibatkan perubahan tekstur dan struktur bahan. Perubahan tersebut tergantung pada suhu dan lama blansing, serta jenis dan kondisi bahan yang diblansing. Umumnya suhu blansing yang digunakan berkisar $55^{\circ} \mathrm{C}$ hingga $80^{\circ} \mathrm{C}$ selama 5 sampai 15 menit (Estiasih, 2009).

Berdasarkan pada pernyataan tersebut maka dilakukan penelitian pengolahan tepung campolay untuk diaplikasikan pada pembuatan biskuit menggunakan buah campolay pada berbagai tingkat kematangan yang berbeda yaitu tingkat kematangan agak tua (mengkal) dan tingkat kematangan tua (matang penuh), dengan suhu blansing yang berbeda.

\section{Metode Penelitian}

Bahan yang digunakan adalah buah campolay yang mengkal dipilih buah yang telah matang dipohon dan buah campolay yang matang digunakan buah matang yang disimpan 2 hari dari hari pemetikan dari Cikalong Wetan. Bahan-bahan kimia yang digunakan dalam analisis kimia adalah $\mathrm{HCl} 3 \%, \mathrm{NaOH}$, aquadest, larutan Luff Schoorl, KI, $\mathrm{H}_{2} \mathrm{SO}_{4} 25 \%, \mathrm{Na}_{2} \mathrm{~S}_{2} \mathrm{O}_{3}, \mathrm{H}_{2} \mathrm{SO}_{4}$ $0,3 \mathrm{~N}, \mathrm{NaOH} 1 \mathrm{~N}$, etanol $95 \%$ dan kloroform, alkohol $90 \%$, iodin, asam asetat.

Alat-alat yang digunakan dalam penelitian ini adalah neraca digital, talenan, pisau, baskom, sendok, pengering, pengayak.

Alat- alat untuk analisis fisik yaitu mangkok, klem, statif dan buret, tabung sentrifuge, sentrifugator, alat viscometer DV-II Pro, gelas kimia dan penangas. Sedangkan alat-alat untuk analisis kimia adalah cawan, spatula, neraca digital, eksikator, spektrofotometer, labu ukur $100 \mathrm{ml}$, tangkrus, oven, kaca arloji, tanur, kertas saring, corong, erlenmeyer $500 \mathrm{~mL}$, batang pengaduk, penangas, cawan porselen, buret, labu pengenceran 500 
$\mathrm{mL}$, soxhlet, klem, statif, pipet tetes, pipet ukur, gelas ukur, dan gelas kimia.

Penelitian ini terdiri dari dua tahap, yaitu penelitian pendahuluan dan penelitian utama. Penelitian pendahuluan bertujuan untuk untuk menentukan waktu pengeringan buah campolay hingga didapatkan tepung dengan kadar air mendekati standar kadar air tepung terigu yaitu maksimal 14,5\% dengan menguji kadar air campolay kering yang telah digiling dan diayak.

Penelitian utama bertujuan untuk mengetahui karakteristik tepung campolay untuk biskuit yang dipengaruhi oleh tingkat kematangan dan suhu blansing yang berbeda. Selanjutnya dilakukan analisis tepung campolay antara lain penentuan rendemen, daya serap air, kelarutan, swelling power, kadar air, kadar pati, kadar gula, kadar lemak, kadar serat kasar, dan kadar abu. Selanjutnya tepung campolay terpilih diuji sifat amilografi dan kadar amilosa. Pada penelitian tahap 2 tepung hasil pengujian terpilih diaplikasikan pada pembuatan biskuit.

Rancangan perlakuan pada penelitian ini terdiri dari dua faktor, yaitu tingkat kematangan campolay $(\mathrm{K})$ yang terdiri dari dua taraf (k1=mengkal dan $\mathrm{k} 2=$ matang); dan suhu blansing (S) yang terdiri dari tiga taraf, yaitu $\mathrm{s}_{1}=50^{\circ} \mathrm{C} ; \mathrm{s}_{2}=60^{\circ} \mathrm{C}$ dan $\mathrm{s}_{3}=70^{\circ}$

Rancangan percobaan yang dilakukan pada penelitian ini adalah Rancangan Acak Kelompok (RAK) dengan pola faktorial $2 \times 3$ dengan 4 kali pengulangan didapatkan 6 kombinasi perlakuan yang masing-masing 4 kali ulangan sehingga diperoleh 24 satuan percobaan. Respon fisik yang dilakukan pada penelitian adalah uji daya serap air tepung (Muchtadi, dkk., 2013), uji kelarutan (Kainuma dkk, 1967), dan uji swelling power (Li, 2001) serta penentuan rendemen tepung (Hafiz, 2008). Respon fisik tepung terpilih yaitu uji sifat amilografi dengan Brookfield Viscometer (Brookfield Engineering Labs., Inc, 2005).

Rancangan Respon pada penelitian ini meliputi respon kimia, fisik dan organoleptik. Respon kimia yang dilakukan, yaitu kadar air metode destilasi (Sudarmadji, 2010); kadar pati metode Luff Schoorl (AOAC, 2005); kadar gula metode Luff Schoorl (AOAC, 2005); kadar lemak metode Soxhlet (AOAC, 2005); kadar serat kasar metode gravimetri (Sudarmadji, 2010); kadar abu metode gravimetri (AOAC, 2005), serta kadar amilosa metode spektrofotometri (SNI 6128:2008). Respon Organoleptik Biskuit (Soekarto, 2006) dilakukan untuk menentukan diterima atau tidaknya suatu produk oleh konsumen yang diwakili oleh panelis. Uji yang dilakukan adalah uji kesukaan dengan menggunakan metode hedonik. Adapun penilaian yang diberikan untuk tepung campolay meliputi warna dan aroma. Sedangkan respon organoleptik untuk biskuit, parameter uji yang digunakan adalah warna, kerenyahan dan rasa. Pengujian dilakukan oleh 30 orang panelis agak terlatih.

\section{Hasil dan Pembahasan}

\section{Hasil Penelitian Pendahuluan}

1. Lama pengeringan

Hasil penelitian penentuan waktu pengeringan dalam pembuatan tepung campolay dapat dilihat pada Tabel 2.

Tabel 1. Hasil Penentuan Waktu Pengeringan pada Pembuatan Tepung Campolay.

\begin{tabular}{|c|c|}
\hline Waktu Pengeringan & Kadar Air (\%) \\
\hline 10 jam & 21 \\
\hline 15 jam & 16 \\
\hline 20 jam & 13 \\
\hline
\end{tabular}

Berdasarkan hasil penelitian tersebut waktu pengeringan yang dipilih adalah 20 jam karena kadar air yang dihasilkan mendekati kadar air tepung terigu sebagai bahan baku makanan yaitu 14,5\%.

Kadar air menurun seiring bertambahnya waktu pengeringan, hal ini disebabkan semakin lama bahan dikeringkan maka air yang teruapkan semakin banyak. Hal ini juga berkaitan dengan udara kering pada pengering yang digunakan dimana semakin lama waktu yang digunakan semakin lama aliran udara kering di dalamnya untuk menampung uap air yang menyebabkan semakin banyak air yang keluar dari bahan tersebut (Nurba, 2008).

Dalam mencegah kerusakan selama masa penyimpanan, pengendalian kadar air merupakan faktor penting. Selama masa penyimpanan kadar air bahan akan bergerak menuju kadar air kesetimbangan, dimana bahan tidak lagi menyerap atau melepaskan uap air (Nurba, 2008). Pengeringan mekanis untuk menurunkan kadar air sampai $13 \%$ selama 20 jam bertujuan agar pada saat masa simpan bila terjadi kenaikan kadar air diharapkan tidak melebihi kadar air 14,5\%.

\section{Analisis Bahan Baku}

Hasil analisis bahan baku buah campolay dapat dilihat pada Tabel 3.

Tabel 2. Hasil Analisis Bahan Baku Campolay Mengkal dan Matang

\begin{tabular}{|c|c|c|}
\hline Komponen & $\begin{array}{c}\text { Campolay } \\
\text { Mengkal }\end{array}$ & $\begin{array}{c}\text { Campolay } \\
\text { Matang }\end{array}$ \\
\hline Air & $46,58 \%$ & $48,20 \%$ \\
\hline Pati & $22,78 \%$ & $20,48 \%$ \\
\hline Gula Pereduksi & $7,86 \%$ & $9,63 \%$ \\
\hline Lemak & $0,61 \%$ & $0,50 \%$ \\
\hline
\end{tabular}

Berdasarkan tabel hasil analisis, terlihat bahwa campolay yang digunakan sebagai bahan baku baik mengkal dan matang dalam pembuatan tepung campolay memiliki kandungan yang tidak jauh berbeda dengan data campolay dalam beberapa literatur, salah satunya data penelitian yang dilakukan di Kuba dan Filipina oleh Verheij dan Coronel (1997), campolay mengandung lemak sebesar 0,1 hingga $0,6 \%$, sedangkan kadar air campolay sebesar 57,2 hingga 60,6 $\%$. Kadar pati dan gula belum dilakukan penelitian.

Perbedaan yang terlihat pada komponen air dari data penelitian sebelumnya dapat disebabkan oleh 
perbedaan tingkat kematangan buah yang digunakan sebagai sampel, umur fisiologis, penanganan bahan baku sebelum pengolahan dan peralatan penelitian yang digunakan dalam analisis. Hal ini sesuai dengan pernyataan Hamsah (2013) yang menyatakan bahwa jumlah nutrisi dalam tanaman berbeda tergantung umur fisiologis, kondisi agronomis, dan lingkungan walaupun tanaman tersebut masih dalam satu varietas yang sama.

Perbedaan kadar komponen air, pati, gula dan lemak antara buah campolay mengkal dan matang dikarenakan proses metabolisme yang berbeda pada tingkat kematangan yang berbeda. Pada buah matang terjadi proses perombakan komponen seperti pati menjadi lebih sederhana yang menyebabkan peningkatan kadar gula, sedangkan kadar pati akan menurun dibandingkan dengan buah yang mengkal. Kadar air akan semakin meningkat seiring dengan bertambahnya tingkat kematangan buah campolay. Hal ini ada hubungannya dengan reaksi respirasi buah dimana hasil akhir dari reaksi ini adalah berupa air dan dengan terjadinya hidrolisis komponen dinding sel seperti selulosa, hemiselulosa dan pektin menyebabkan buah kehilangan tekanan turgor akibat bocornya sel dan air sel keluar.

\section{Hasil Penelitian Utama}

\section{Kadar Air}

Berdasarkan hasil perhitungan ANAVA terhadap kadar air menunjukkan bahwa tingkat kematangan dan suhu blansing berpengaruh nyata terhadap tepung campolay yang dihasilkan. Hasil uji lanjut terhadap kadar air tepung campolay dapat dilihat pada Tabel 4 dan Tabel 5.

Tabel 3. Pengaruh Tingkat Kematangan terhadap Kadar Air

\begin{tabular}{|l|l|}
\hline Perlakuan & Hasil Rata-Rata (\%) \\
\hline k1 (mengkal) & $10,45 \mathrm{a}$ \\
\hline $\mathrm{k} 2$ (matang) & $12,20 \mathrm{~b}$ \\
\hline
\end{tabular}

Tabel 4. Pengaruh Suhu Blansing terhadap Kadar Air

\begin{tabular}{|l|l|}
\hline Perlakuan & Hasil Rata-Rata $(\%)$ \\
\hline $\mathrm{s} 1\left(50^{\circ} \mathrm{C}\right)$ & $12,82 \mathrm{c}$ \\
\hline $\mathrm{s} 2\left(60^{\circ} \mathrm{C}\right)$ & $11,50 \mathrm{~b}$ \\
\hline $\mathrm{s} 3\left(70^{\circ} \mathrm{C}\right)$ & $9,65 \mathrm{a}$ \\
\hline
\end{tabular}

Keterangan : Nilai Rata-rata yang diikuti huruf berbeda menunjukkan perbedaan nyata pada taraf 5\% menurut uji lanjut Duncan.

Pada tepung campolay dengan meningkatnya kematangan menyebabkan peningkatan kadar air tepung campolay, hal ini disebabkan semakin tinggi tingkat kematangan buah secara umum maka kadar air meningkat (Julianti, 2011). Hal ini sesuai dengan pernyataan Karim (2016) bahwa buah mentah yang menjadi matang selalu bertambah kandungan airnya.

Kadar air pada tepung campolay seiring dengan bertambahnya suhu blansing semakin menurun kadarnya, hal ini disebabkan oleh proses blansing dimana semakin tinggi suhu yang digunakan mengakibatkan sifat permeabel dinding sel meningkat, sehingga memudahkan penguapan air keluar dari dalam bahan saat pengeringan. Pada saat proses blansing terjadi pemekaran dan pengembangan struktur granula pati. Granula pati tersebut akan menyerap air sehingga uap air yang terserap dalam bahan akan semakin banyak. Pengembangan struktur bahan menyebabkan rongga pada bahan tersebut akan semakin luas dan mudah menyerap air tetapi mudah untuk melepas air ketika proses pengeringan (Ayu dan Yuwono, 2014).

Berdasarkan hasil penelitian kadar air tepung campolay rata-rata kadar air berkisar antara 8,81\% hingga $13,62 \%$ telah memenuhi Standar Nasional Indonesia 01-3751-2000 tentang standar tepung terigu yang kadar air maksimumnya 14,5\% dan untuk kadar air maksimum tepung ubi jalar sebagai salah satu tepung non terigu yaitu 7 hingga 11\% (Choliq, dkk., 2009) serta kadar air maksimal tepung singkong adalah $12 \%$ (SNI 01-2997-1996).

\section{Kadar Pati}

Berdasarkan hasil perhitungan ANAVA terhadap kadar pati menunjukkan bahwa tingkat kematangan dan suhu blansing berpengaruh nyata terhadap tepung campolay yang dihasilkan Hasil uji lanjut terhadap kadar pati tepung campolay dapat dilihat pada Tabel 6 dan Tabel 7.

Tabel 5. Pengaruh Tingkat Kematangan terhadap Kadar Pati

\begin{tabular}{|l|l|}
\hline Perlakuan & Hasil Rata-Rata (\%) \\
\hline k1 (mengkal) & $45,04 \mathrm{~b}$ \\
\hline k2 (matang) & $43,51 \mathrm{a}$ \\
\hline
\end{tabular}

Tabel 6. Pengaruh Suhu Blansing terhadap Kadar Pati

\begin{tabular}{|l|l|}
\hline Perlakuan & Hasil Rata-Rata (\%) \\
\hline $\mathrm{s} 1\left(50^{\circ} \mathrm{C}\right)$ & $45,22 \mathrm{c}$ \\
\hline $\mathrm{s} 2\left(60^{\circ} \mathrm{C}\right)$ & $44,25 \mathrm{~b}$ \\
\hline $\mathrm{s} 3\left(70^{\circ} \mathrm{C}\right)$ & $43,36 \mathrm{a}$ \\
\hline
\end{tabular}

Keterangan: Nilai rata-rata yang ditandai dengan huruf yang sama menunjukkan tidak berbeda nyata pada taraf 5\% Uji Duncan.

Pada tepung campolay dengan meningkatnya kematangan menyebabkan penurunan kadar pati tepung campolay, hal ini disebabkan semakin tinggi tingkat kematangan buah maka kandungan pati dalam buah akan menurun akibat peningkatan kadar gula. Hal ini sesuai dengan pernyataan Pantastico (1997) Selama pematangan zat pati seluruhnya terhidrolisis dan terbentuk gula-gula pereduksi, serta kebanyakan karbohidrat terlarut lainnya mengalami metabolisme selama pematangan buah. Winarno (2008) juga menyatakan bahwa kandungan pati buah secara umum berubah menjadi gula-gula pereduksi yang akan menimbulkan rasa manis.

Dalam proses pematangan perubahan penting adalah penguraian pati, yang umumnya hampir semua dikonversikan menjadi gula. Penguraian ini dikatalisa oleh enzim amilase yang menghidrolisa pati menjadi maltosa dan dihidrolisa lebih lanjut oleh enzim maltase menjadi glukosa (Hariyadi dan Aini, 2015)

Kadar pati pada tepung campolay seiring dengan bertambahnya suhu blansing semakin menurun 
kadarnya, hal ini diduga karena kandungan pati ketika proses blansing mengalami gelatinisasi akibat perlakuan suhu yang tinggi. Pati yang tergelatinisasi selanjutnya lebih mudah diuraikan menjadi gula reduksi, sehingga kadar pati menurun (Ayu dan Yuwono, 2014).

Berdasarkan hasil penelitian rata-rata kadar pati tepung campolay berkisar antara 42,55\% hingga $46 \%$. Kadar pati ini lebih rendah dibandingkan kadar pati dari tepung non terigu lainnya seperti tepung ubi jalar dengan kandungan pati 55\% (Antarlina, 1999), tepung beras 67,68\% (Imanningsih, 2012) dan SNI 01-29971996 standar mutu tepung singkong dengan kandungan pati $75 \%$

\section{Kadar Gula Reduksi}

Berdasarkan hasil perhitungan ANAVA terhadap kadar gula reduksi menunjukkan bahwa tingkat kematangan dan suhu blansing berpengaruh nyata terhadap tepung campolay yang dihasilkan. Hasil uji lanjut terhadap kadar gula pereduksi tepung campolay dapat dilihat pada Tabel 8 dan Tabel 9.

Tabel 7. Pengaruh Tingkat Kematangan terhadap Gula Reduksi

\begin{tabular}{|l|l|}
\hline Perlakuan & Hasil Rata-Rata (\%) \\
\hline k1 (mengkal) & $12,24 \mathrm{a}$ \\
\hline k2 (matang) & $12,82 \mathrm{~b}$ \\
\hline
\end{tabular}

Keterangan: Nilai rata-rata yang ditandai dengan huruf yang sama menunjukkan tidak berbeda nyata pada taraf 5\% Uji Duncan.

Tabel 8. Pengaruh Suhu Blansing terhadap Kadar Gula Reduksi

\begin{tabular}{|l|l|}
\hline Perlakuan & Hasil Rata-Rata $(\%)$ \\
\hline s1 $\left(50^{\circ} \mathrm{C}\right)$ & $12,11 \mathrm{a}$ \\
\hline $\mathrm{s} 2\left(60^{\circ} \mathrm{C}\right)$ & $12,51 \mathrm{~b}$ \\
\hline $\mathrm{s} 3\left(70^{\circ} \mathrm{C}\right)$ & $12,98 \mathrm{c}$ \\
\hline
\end{tabular}

Keterangan: Nilai rata-rata yang ditandai dengan huruf yang sama menunjukkan tidak berbeda nyata pada taraf 5\% Uji Duncan.

Kadar gula reduksi pada tepung campolay semakin meningkat kadarnya seiring dengan bertambahnya suhu blansing, hal ini dapat disebabkan oleh berubahnya pati menjadi gula reduksi diakibatkan oleh suhu tinggi. Pada tepung campolay dengan meningkatnya kematangan menyebabkan peningkatan kadar gula reduksi tepung campolay, hal ini disebabkan semakin tinggi tingkat kematangan buah maka kandungan pati dalam buah secara umum berubah menjadi gula-gula pereduksi (Winarno, 2008). Hal ini didukung oleh Hadiwiyoto dan Soehardi (1981) yang menyatakan bahwa karbohidrat dibentuk melalui proses fotosintesis dalam bentuk tepung, kemudian tepung diubah menjadi sukrosa dan gula-gula reduksi yaitu glukosa dan fruktosa. Perubahan ini tergantung suhu, waktu dan tingkat masak fisiologis hasil pertanian, misalnya saat pemetikan, tingkat pemasakan dan lainlain. Tingkat umur (kemasakan) yang berbeda-beda itu menyebabkan perbedaan sifatnya. Perbedaan sifat ini jelas terlihat pada kandungan zat-zat penyusunnya seperti gula reduksi.
Berdasarkan hasil penelitian kadar gula reduksi tepung campolay berkisar antara $11,78 \%$ hingga $13,26 \%$. Mutu tepung buah yang baik sangat ditentukan oleh tingkat umur panen. Semakin rendah kandungan gula reduksi yang dihasilkan, dapat menghasilkan tepung yang bermutu baik (Radiena, 2016).

\section{Kadar Lemak}

Berdasarkan perhitungan ANAVA menunjukkan bahwa tingkat kematangan, suhu blansing serta interaksi keduanya tidak berpengaruh nyata terhadap kadar lemak tepung campolay. Hasil analisis variasi dapat dilihat pada Tabel 10

Tabel 9. Hasil Analisis Kadar Lemak Tepung Campolay

\begin{tabular}{|l|l|}
\hline Sampel & Hasil Rata-Rata \\
\hline k1s1 & $0,55 \mathrm{a}$ \\
\hline $\mathrm{k} 1 \mathrm{~s} 2$ & $0,53 \mathrm{a}$ \\
\hline $\mathrm{k} 1 \mathrm{~s} 3$ & $0,51 \mathrm{a}$ \\
\hline $\mathrm{k} 2 \mathrm{~s} 1$ & $0,54 \mathrm{a}$ \\
\hline $\mathrm{k} 2 \mathrm{~s} 2$ & $0,51 \mathrm{a}$ \\
\hline k2s3 & $0,50 \mathrm{a}$ \\
\hline
\end{tabular}

Keterangan: Nilai rata-rata yang ditandai dengan huruf yang sama menunjukkan tidak berbeda nyata pada taraf 5\% Uji Duncan.

Tabel di atas menunjukkan bahwa semakin tinggi suhu blansing dan semakin matang buah campolay tidak berpengaruh terhadap kadar lemak tepung campolay, hal ini dapat disebabkan kerusakan dan penurunan kandungan lemak selama proses blansing dan selama pematangan tidak terlalu besar, sehingga komponen gizi lemak yang berubah disebabkan oleh pecahnya komponen-komponen lemak menjadi produk volatil, seperti aldehid, keton, alkohol, asam-asam dan hidrokarbon juga tidak terlalu besar (Apriliyanti, 2010). Lemak yang menurun kadarnya selama pematangan atau pada saat pembentukan pigmen tidak terlalu besar seperti terlihat pada tabel di atas dapat disebabkan tingkat kematangan yang tidak terlalu jauh jaraknya (Hariyadi dan Aini, 2015).

Berdasarkan hasil penelitian rata-rata kadar lemak berkisar antara 0,50\% hingga 0,55\% sama bila dibandingkan kadar lemak dari tepung non terigu seperti tepung ubi jalar dengan kandungan lemak 0,50\% hingga 1,02\% (Choliq, dkk., 2009).

\section{Kadar Abu}

Berdasarkan hasil perhitungan ANAVA terhadap kadar abu menunjukkan bahwa suhu blansing berpengaruh nyata terhadap tepung campolay yang dihasilkan. Hasil uji lanjut terhadap kadar abu tepung campolay dapat dilihat pada Tabel 11 .

Tabel 10. Pengaruh Suhu Blansing terhadap Kadar Abu

\begin{tabular}{|l|l|}
\hline Perlakuan & Hasil Rata-Rata (\%) \\
\hline s1 $\left(50^{\circ} \mathrm{C}\right)$ & $3,65 \mathrm{a}$ \\
\hline s2 $\left(60^{\circ} \mathrm{C}\right)$ & $3,84 \mathrm{~b}$ \\
\hline s3 $\left(70^{\circ} \mathrm{C}\right)$ & $3,96 \mathrm{c}$ \\
\hline
\end{tabular}

Keterangan: Nilai rata-rata yang ditandai dengan huruf yang sama menunjukkan tidak berbeda nyata pada taraf $5 \%$ Uji Duncan.

Peningkatan kadar abu terjadi seiring dengan meningkatnya suhu blansing yang ditunjukkan dalam 
tabel disebabkan oleh banyaknya air yang teruapkan dari bahan. Hal ini berkaitan dengan kadar air pada tepung campolay yang menurun dengan semakin tingginya suhu blansing, hal ini disebabkan oleh proses blansing dimana semakin tinggi suhu yang digunakan mengakibatkan sifat permeabel dinding sel meningkat, sehingga memudahkan penguapan air keluar dari dalam bahan saat pengeringan. Hal ini sesuai dengan pernyataan Sudarmadji (2010) bahwa kadar abu tergantung pada jenis bahan, cara pengabuan, waktu dan suhu yang digunakan saat pengeringan. Peningkatan kadar abu berkaitan dengan semakin besarnya air yang keluar dari dalam bahan.

Penentuan kadar abu dapat digunakan untuk berbagai tujuan, antara lain untuk menentukan baik tidaknya suatu pengolahan, mengetahui jenis bahan yang digunakan dan sebagai penentu parameter nilai gizi suatu bahan (Kartono, 2015). Menurut Suarni (2009) kadar abu pada tepung mempengaruhi proses dan hasil akhir produk, antara lain warna produk dan tingkat kestabilan adonan. Semakin tinggi kadar abu semakin buruk kualitas tepung dan sebaliknya. Tingginya kadar abu menunjukkan tingginya komponen mineral.

Berdasarkan hasil penelitian rata-rata kadar abu berkisar antara 3,62\% hingga 4,04\%. Kadar abu ini sebanding dengan kadar abu dari tepung non terigu lainnya seperti tepung ubi jalar dengan kandungan abu 2,58 hingga 4,71\% (Choliq, dkk., 2009), tetapi lebih tinggi dibanding kadar abu tepung singkong sebesar 1,5\% (Badan Standarisasi Nasional : SNI 01-29971996) dan abu pada tepung terigu dengan kadar abu 0,6\% (SNI 01-3751-2006).

\section{Kadar Serat Kasar}

Berdasarkan hasil perhitungan ANAVA terhadap kadar serat kasar menunjukkan bahwa suhu blansing berpengaruh nyata terhadap tepung campolay yang dihasilkan. Hasil uji lanjut terhadap kadar serat kasar tepung campolay dapat dilihat pada Tabel 20 .

Tabel 11. Pengaruh Suhu Blansing terhadap Kadar Serat Kasar

\begin{tabular}{|l|l|}
\hline Perlakuan & Hasil Rata-Rata $(\%)$ \\
\hline s1 $\left(50^{\circ} \mathrm{C}\right)$ & $6,33 \mathrm{c}$ \\
\hline $\mathrm{s} 2\left(60^{\circ} \mathrm{C}\right)$ & $5,88 \mathrm{~b}$ \\
\hline $\mathrm{s} 3\left(70^{\circ} \mathrm{C}\right)$ & $5,03 \mathrm{a}$ \\
\hline
\end{tabular}

Keterangan: Nilai rata-rata yang ditandai dengan huruf yang sama menunjukkan tidak berbeda nyata pada taraf 5\% Uji Duncan.

Penurunan serat kasar tepung campolay seiring dengan bertambahnya suhu blansing disebabkan oleh dinding sel dari bahan berubah selama proses blansing yang menyebabkan turunnya kadar serat kasar pada bahan, karena struktur gel pektin dan hemiselulosa rusak oleh pemanasan pada saat blansing (Kusumawati, dkk., 2012). Hal ini didukung dengan pernyataan Hariyadi dan Aini (2015) dimana terjadi penurunan serat yang tidak larut asam dan basa karena adanya penurunan polisakarida akibat terhidrolisis.
Berdasarkan hasil penelitian rata-rata kadar serat kasar berkisar antara 5\% hingga 6,63\%. Kadar serat kasar ini sebanding dengan kadar serat kasar tepung ubi jalar kuning yaitu 5,54\%, tetapi lebih tinggi dibandingkan dengan kadar serat kasar dari tepung ubi jalar varietas lain dengan kandungan serat kasar sebesar 1,95\% hingga 4,72\% (Choliq, dkk., 2009) dan tepung singkong maksimal 4\% (SNI 01-2997-1996).

\section{Rendemen}

Berdasarkan hasil perhitungan ANAVA pada lampiran 4, halaman 96 terhadap rendemen menunjukkan bahwa tingkat kematangan dan suhu blansing berpengaruh nyata terhadap tepung campolay yang dihasilkan. Hasil uji lanjut terhadap rendemen tepung campolay dapat dilihat pada Tabel 13 dan Tabel 14.

Tabel 12. Pengaruh Tingkat Kematangan terhadap Rendemen

\begin{tabular}{|l|l|}
\hline Perlakuan & Hasil Rata-Rata (\%) \\
\hline k1 (mengkal) & $27,32 \mathrm{~b}$ \\
\hline k2 (matang) & $26,39 \mathrm{a}$ \\
\hline
\end{tabular}

Tabel 13. Pengaruh Suhu Blansing terhadap Rendemen

\begin{tabular}{|l|l|}
\hline Perlakuan & Hasil Rata-Rata $(\%)$ \\
\hline s1 $\left(50^{\circ} \mathrm{C}\right)$ & $27,82 \mathrm{c}$ \\
\hline s2 $\left(60^{\circ} \mathrm{C}\right)$ & $26,97 \mathrm{~b}$ \\
\hline s3 $\left(70^{\circ} \mathrm{C}\right)$ & $25,78 \mathrm{a}$ \\
\hline
\end{tabular}

Keterangan: Nilai rata-rata yang ditandai dengan huruf yang sama menunjukkan tidak berbeda nyata pada taraf $5 \%$ Uji Duncan.

Persentase rendemen tepung campolay mengalami penurunan dengan bertambahnya suhu blansing dan tingkat kematangan. Hal ini dapat disebabkan semakin tinggi suhu blansing menyebabkan terjadinya gelatinisasi dan penyusutan berat buah sehingga rendemen yang dihasilkan semakin rendah hal ini sesuai dengan pernyataan Effendi (2009) pada bahan pangan yang diblansing, terjadi penyusutan yang sangat besar sehingga menyebabkan kehilangan berat bahan yang cukup tinggi. Kehilangan berat ini dapat mencapai $19 \%$ yang diakibatkan oleh kondisi suhu $50^{\circ} \mathrm{C}$ sampai $55^{\circ} \mathrm{C}$.

Berdasarkan hasil penelitian rata-rata rendemen tepung berkisar antara 26,19\% hingga 28,33\%. Rendemen tepung campolay ini sebanding dengan rendemen tepung non terigu seperti tepung ubi jalar dengan persentase rendemen tepung sebesar 26,58\% hingga 29,58\% (Apriliyanti, 2010).

\section{Daya Serap Air}

Berdasarkan hasil perhitungan ANAVA terhadap daya serap air menunjukkan bahwa suhu blansing berpengaruh nyata terhadap tepung campolay yang dihasilkan. Hasil uji lanjut terhadap daya serap air tepung campolay dapat dilihat pada Tabel 15 .

Tabel 14. Pengaruh Suhu Blansing terhadap Daya Serap Air

\begin{tabular}{|l|l|}
\hline Perlakuan & Hasil Rata-Rata (\%) \\
\hline
\end{tabular}




\begin{tabular}{|l|l|}
\hline $\mathrm{s} 1\left(50^{\circ} \mathrm{C}\right)$ & $45,00 \mathrm{a}$ \\
\hline $\mathrm{s} 2\left(60^{\circ} \mathrm{C}\right)$ & $45,96 \mathrm{~b}$ \\
\hline $\mathrm{s} 3\left(70^{\circ} \mathrm{C}\right)$ & $47,93 \mathrm{c}$ \\
\hline
\end{tabular}

Keterangan: Nilai rata-rata yang ditandai dengan huruf yang sama menunjukkan tidak berbeda nyata pada taraf 5\% Uji Duncan.

Peningkatan daya serap air tepung dengan bertambahnya suhu blansing terkait dengan kadar air dalam tepung, pada data kadar air sebelumnya seiring bertambahnya suhu blansing kadar air tepung yang dihasilkan semakin rendah, sedangkan dengan bertambahnya kematangan buah menyebabkan penurunan daya serap air diakibatkan kenaikan kadar air pada tepung, hal ini sesuai dengan pernyataan Suarni (2012) dimana kemampuan daya serap air tepung berkurang bila kadar air dalam tepung terlalu tinggi.

Berdasarkan hasil penelitian rata-rata daya serap air tepung berkisar antara 44,91\% hingga 48,03\%. Kelarutan tepung campolay ini sebanding dengan daya serap air tepung non terigu seperti tepung ubi jalar dengan persentase daya serap air tepung sebesar $41,31 \%$ hingga 47,69\% (Apriliyanti, 2010).

\section{Kelarutan}

Berdasarkan hasil perhitungan ANAVA terhadap kelarutan menunjukkan bahwa tingkat kematangan dan suhu blansing berpengaruh nyata terhadap tepung campolay yang dihasilkan. Hasil uji lanjut terhadap kelarutan tepung campolay dapat dilihat pada Tabel 16 dan Tabel 17.

Tabel 15. Pengaruh Tingkat Kematangan terhadap Kelarutan

\begin{tabular}{|l|l|}
\hline Perlakuan & Hasil Rata-Rata (\%) \\
\hline k1 (mengkal) & $39,67 \mathrm{a}$ \\
\hline k2 (matang) & $41,66 \mathrm{~b}$ \\
\hline
\end{tabular}

Tabel 16. Pengaruh Suhu Blansing terhadap Kelarutan

\begin{tabular}{|l|l|}
\hline Perlakuan & Hasil Rata-Rata $(\%)$ \\
\hline s1 $\left(50^{\circ} \mathrm{C}\right)$ & $39,28 \mathrm{a}$ \\
\hline $\mathrm{s} 2\left(60^{\circ} \mathrm{C}\right)$ & $40,46 \mathrm{~b}$ \\
\hline $\mathrm{s} 3\left(70^{\circ} \mathrm{C}\right)$ & $42,25 \mathrm{c}$ \\
\hline
\end{tabular}

Keterangan: Nilai rata-rata yang ditandai dengan huruf yang sama menunjukkan tidak berbeda nyata pada taraf 5\% Uji Duncan.

Berdasarkan pada hasil di atas kelarutan tepung campolay meningkat dengan bertambahnya suhu blansing, dan juga meningkat dengan bertambahnya tingkat kematangan. Hal ini dapat disebabkan oleh pati dalam buah campolay dimana semakin tinggi suhu blansing, pati buah terhidrolisis dan berubah dari bentuk karbohidrat yang kompleks (polisakarida) menjadi karbohidrat atau gula sederhana yang lebih mudah larut dalam air. Begitu pula dengan meningkatnya kematangan buah campolay, Maharani, dkk., (2015) mengemukakan bahwa dalam proses metabolisme buah, pati mengalami perombakan menjadi glukosa, fruktosa, dan gula pereduksi lainnya yang lebih mudah larut dalam air. Berdasarkan pada pernyataan tersebut dapat diketahui kelarutan tepung campolay dalam air menjadi meningkat seiring dengan meningkatnya suhu blansing dan kematangannya.
Berdasarkan hasil penelitian rata-rata kelarutan tepung berkisar antara 38,2\% hingga 42,98\%. Kelarutan tepung campolay ini lebih rendah dibandingkan dengan kelarutan tepung non terigu seperti tepung ubi jalar dengan persentase kelarutan tepung sebesar $45 \%$ hingga 53,22\% (Antarlina, 1999).

\section{Swelling Power}

Berdasarkan hasil perhitungan ANAVA terhadap swelling power menunjukkan bahwa suhu blansing berpengaruh nyata terhadap tepung campolay yang dihasilkan. Hasil uji lanjut terhadap swelling power tepung campolay dapat dilihat pada Tabel 18 .

Tabel 17. Pengaruh Suhu Blansing terhadap Swelling Power

\begin{tabular}{|c|c|}
\hline Perlakuan & Hasil Rata-Rata $(\mathrm{g} / \mathrm{g})$ \\
\hline $\mathrm{s} 1\left(50^{\circ} \mathrm{C}\right)$ & $6,44 \mathrm{a}$ \\
\hline $\mathrm{s} 2\left(60^{\circ} \mathrm{C}\right)$ & $6,61 \mathrm{~b}$ \\
\hline $\mathrm{s} 3\left(70^{\circ} \mathrm{C}\right)$ & $6,79 \mathrm{c}$ \\
\hline
\end{tabular}

Keterangan: Nilai rata-rata yang ditandai dengan huruf yang sama menunjukkan tidak berbeda nyata pada taraf 5\% Uji Duncan.

Hasil menunjukkan semakin tinggi suhu blansing semakin meningkat daya pengembangannya. Peningkatan swelling power ini diakibatkan pemanasan pati pada suhu yang semakin tinggi, hal ini sesuai dengan hasil penelitian Armiati, dkk., (2015) dimana peningkatan swelling power ini disebabkan kadar amilosa yang semakin rendah atau amilopektin dalam pati lebih tinggi. Semakin tinggi suhu blansing, maka semakin banyak amilosa tereduksi, sehingga penurunan jumlah amilosa tersebut mengakibatkan kenaikan swelling power (Amalia, 2015). Menurut Jading, dkk., (2011), swelling power pada tepung juga dipengaruhi oleh daya serap air. Semakin besar daya serap air menyebabkan swelling power meningkat.

Swelling power yang tinggi berarti semakin tinggi pula kemampuan pati mengembang dalam air (Suriani, 2008). Yuliasih (2007) menyatakan bahwa komponen pati dalam suatu bahan mempengaruhi kemampuan penyerapan air dan daya pengembangan pati (swelling power).

\section{Produk Terpilih}

Berdasarkan hasil skoring, perlakuan k1s3 menjadi tepung terpilih karena memiliki nilai skoring tertinggi, dengan hasil respon kimia sebagai berikut : kadar air sebesar $8,81 \%$, kadar gula $12,7 \%$, kadar pati $44,17 \%$, kadar abu 3,88\%, kadar lemak 0,51\%, kadar serat kasar 5,07\%. Hasil respon fisik meliputi rendemen tepung sebesar $26,19 \%$, kelarutan tepung $41,53 \%$, daya serap air sebesar 48,03\% dan swelling power $6,78 \mathrm{~g} / \mathrm{g}$.

Tepung campolay terpilih dilakukan pengujian sifat amilografi dan kadar amilosa dengan hasil sebagai berikut:

Tabel 18. Data Hasil Penelitian Sifat Amilografi dan Kadar Amilosa

\begin{tabular}{|c|c|c|c|c|c|c|}
\hline \multirow{3}{*}{ Kode } & \multicolumn{2}{|c|}{ Gelatinisasi } & \multicolumn{2}{c|}{$\begin{array}{c}\text { Viskositas } \\
\text { Puncak (Cp) }\end{array}$} & $\begin{array}{c}\text { Visko- } \\
\text { sitas }\end{array}$ & $\begin{array}{c}\text { Kadar } \\
\text { Amilos }\end{array}$ \\
\cline { 2 - 4 } & $\begin{array}{c}\text { Waktu } \\
\text { (menit) }\end{array}$ & $\begin{array}{c}\text { Suhu } \\
\left({ }^{\circ} \mathrm{C}\right)\end{array}$ & $\begin{array}{c}\text { Wakt } \\
\mathrm{u}\end{array}$ & $\begin{array}{c}\text { Suh } \\
\mathrm{u}\end{array}$ & $\begin{array}{c}\text { Balik } \\
(\mathrm{Cp})\end{array}$ & \begin{tabular}{c}
$\mathrm{a}(\%)$ \\
\hline
\end{tabular}
\end{tabular}




\begin{tabular}{|c|c|c|c|c|c|c|}
\hline & & & $\begin{array}{c}(\mathrm{men} \\
\text { it })\end{array}$ & $\left({ }^{\circ} \mathrm{C}\right)$ & & \\
\hline $\mathrm{k} 1 \mathrm{~s} 3$ & 5,08 & 58,45 & - & - & 356,71 & 17,15 \\
\hline
\end{tabular}

Menurut Scoch dan Maywald (1968) dalam Utami (2010) pati yang telah mencapai suhu awal gelatinisasi akan menyerap air dan mengalami peningkatan viskositas. Penyerapan air secara terus menerus akan meningkatkan viskositas pasta pati sampai akhirnya granula pati akan pecah kemudian mengalami penurunan viskositas. Namun pada penelitian ini, hal tersebut tidak ditemukan pada tepung campolay, sehingga pada tabel di atas viskositas puncak tepung campolay tidak dapat diketahui. Hal ini dikarenakan tepung campolay terus mengalami peningkatan viskositas selama proses pemanasan dan pendinginan sehingga tidak ada viskositas puncak.

Tepung untuk olahan pangan ragam jenis dan fungsinya contohnya terdapat tepung Tang Mien atau Tang Flour, merupakan endapan (sari pati) dari tepung terigu, lalu diambil glutennya. Fungsi tepung ini salah satunya untuk hasil akhir tampilan kulit dim sum tampak bening/transparan. Selanjutnya terdapat tepung putih telur yang digunakan sebagai sumber protein dalam olahan pangan, dan ada tepung custard khusus untuk membuat vla yang dibuat dari campuran tepung kentang (atau maizena), gula, susu dan kuning telur dan bahan pengental lainnya.

\section{Pengaplikasian pada Biskuit}

Berdasarkan hasil pengamatan uji organoleptik pada lampiran 6 halaman 107 tingkat kesukaan panelis terhadap warna, kerenyahan dan rasa biskuit menunjukkan bahwa biskuit dengan kode 172 (perbandingan tepung campolay dan tepung terigu 75 : 25) memiliki nilai rata-rata tertinggi dengan penilaian suka (skala 4). Hasil rata-rata terbesar dari masingmasing atribut dapat dilihat pada tabel 20.

Tabel 19. Hasil Perhitungan Rata-rata Biskuit

\begin{tabular}{|c|c|c|c|c|}
\hline \multirow{2}{*}{$\begin{array}{c}\text { KODE } \\
\text { SAMPEL }\end{array}$} & \multicolumn{3}{|c|}{ RATA-RATA } & \multirow{2}{*}{ Tar } \\
\cline { 2 - 4 } na & $\begin{array}{c}\text { Kere } \\
\text { nyah } \\
\text { an }\end{array}$ & Rasa & TOTAL \\
\hline $\begin{array}{c}680(25: \\
75)\end{array}$ & 3,23 & 3,20 & 3,27 & 9,70 \\
\hline $\begin{array}{c}461(50: \\
50)\end{array}$ & 3,23 & 3,17 & 3,17 & 9,57 \\
\hline $\begin{array}{c}172(75: \\
25)\end{array}$ & 4,13 & 4,20 & 4,13 & 12,47 \\
\hline $\begin{array}{c}523(100 \\
: 0)\end{array}$ & 3,17 & 3,27 & 3,33 & 9,77 \\
\hline
\end{tabular}

Dari segi warna, biskuit dengan perbandingan tepung campolay dan tepung terigu (75:25) lebih disukai. Warna biskuit yang diterima oleh konsumen adalah warna kuning hingga kuning kecoklatan. Warna coklat pada biskuit campolay yang dihasilkan setelah pemanggangan merupakan reaksi pencoklatan non enzimatis atau reaksi Maillard (Gracia, dkk., 2009).
Uji kesukaan terhadap rasa dan tingkat kerenyahan biskuit campolay menunjukkan biskuit dengan kode 172 lebih disukai oleh panelis. Hal ini dapat disebabkan proporsi yang cukup antara tepung campolay dan tepung terigu serta dengan penambahan mentega, gula dan kuning telur yang tepat sehingga menghasilkan rasa dan tingkat kerenyahan yang disukai panelis.

Berdasarkan hasil penelitian, dapat diambil kesimpulan sebagai berikut :

1. Berdasarkan hasil penelitian, tingkat kematangan buah campolay berpengaruh terhadap karakteristik tepung campolay yaitu pada kadar air, pati, gula reduksi, rendemen tepung dan kelarutan tepung.

2. Suhu blansing buah campolay berpengaruh terhadap kadar air, pati, gula reduksi, abu, serat kasar, rendemen, daya serap air, kelarutan dan swelling power tepung campolay.

3. Kadar lemak tidak dipengaruhi baik oleh tingkat kematangan maupun suhu blansing. Interaksi antara tingkat kematangan dan suhu blansing juga tidak berpengaruh terhadap karakteristik tepung campolay.

4. Penentuan produk terpilih dilihat dari respon fisik dan respon kimia dan perlakuan yang terpilih adalah perlakuan k1s3 (tingkat kematangan mengkal dengan suhu blansing $70^{\circ} \mathrm{C}$ ).

5. Biskuit yang mendapat penilaian paling disukai oleh panelis dari atribut warna, kekerasan dan rasa adalah biskuit dengan kode 172 (perbandingan tepung campolay dan tepung terigu yaitu 75:25).

\section{Daftar Pustaka}

1. Adi, Irwanto. (2016). Alkesa : Klasifikasi, dan Manfaat Buah Alkesa. Retrieved Mei 03, 2017 from Blog from Learning : http://irwantoadi926.blogspot.co.id/2016/10/alkesaklasifikasi-dan-manfaat-buah.html.

2. Afrianti, H. Leni. (2013). Teknologi Pengawetan Pangan. Alfabeta, Bandung.

3. Agustiningrum, Ayu, D., Susilo, Bambang., dan Yulianingsih, Rini. (2014). Studi Pengaruh Konsentrasi Oksigen pada Penyimpanan Atmosfer Termodifikasi Buah Sawo. Jurnal Bioproses Komoditas Tropis Vol. 2, No. 1. Fakultas Teknologi Pertanian, Universitas Brawijaya, Malang.

4. Amalia, A. (2015). Pembuatan Pati. Retrieved September 17, 2017 from : https://arrafidiena2013.wordpress.com/2015/07/29/ pembuatan-pati/

5. Amiruddin, Chaerah. (2013). Pembuatan Tepung Wortel ( Daucus carrota L ) Dengan Variasi Suhu Pengering. Skripsi : Fakultas Pertanian, Universitas Hasanuddin, Makasar.

6. Antarlina, S.S. (1999). Kandungan Gizi, Mutu Tepung Ubi Jalar serta Produk Olahannya. Balai Penelitian Tanaman Pangan, Malang. 
7. AOAC Association of Official Analytical Chemist, (2005). Official Method of Analysis of The Association of Official Analytical of Chemist. Arlington: The Association of Official Analytical Chemist, Inc.

8. Apriliyanti, Tina., (2010). Kajian Sifat Fisikokimia dan Sensori Tepung Ubi Jalar Ungu (Ipomoea batatas blackie) dengan Variasi Proses Pengeringan. Skripsi, Fakultas Pertanian, Universitas Sebelas Maret.

9. Armiati, Mila., dkk., (2015). Proses Perubahan Pada Pati (Swelling). Fakultas Teknologi Pertanian. Universitas Brawijaya, Malang.

10. Ayu, C. Disafitri, dan Yuwono S. Sudarminto., (2014). Pengaruh Suhu Blansing Dan Lama Perendaman Terhadap Sifat Fisik Kimia Tepung Kimpul (Xanthosoma sagittifolium). Jurnal Pangan dan Agroindustri Vol.2 No.2 p.110120. FTP Universitas Brawijaya, Malang.

11. Badan Standarisasi Nasional, (1996). Tepung Singkong : SNI 01-2997-1996. Jakarta.

12. Badan Standarisasi Nasional, (2006). Tepung Terigu sebagai Bahan Makanan : SNI 01-37512006. Jakarta.

13. Brookfield Engineering Labs., Inc. (2005) Operating Instructions Manual No. M/03-165A0404. Brookfield.

14. Choliq, A., Sarjana, dan Ambarsari, Indrie. (2009). Rekomendasi dalam Penetapan Standar Mutu Tepung Ubi Jalar. Balai Pengkajian Teknologi Pertanian, Jawa Tengah.

15. Effendi, Supli. (2009). Teknologi Pengolahan dan Pengawetan Pangan. Alfabeta. Bandung.

16. Estiasih. (2009). Teknologi Pengolahan Pangan. PT Bumi Aksara. Jakarta.

17. Fitrayana, Chandra. (2014). Pengaruh Lama dan Suhu Pengeringan terhadap Karakteristik Teh Herbal Pare (Momordica charantia L). Skripsi : Fakultas Teknik, Universitas Pasundan, Bandung.

18. Gasperz, Vincent. (2006). Teknik Analisis dalam Penelitian Percobaan (Cetakan Ketiga). Tarsito, Bandung.

19. Gracia, Cynthia, Sugiyono dan Haryanto, Bambang. (2009). Kajian Formulasi Biskuit Jagung dalam Rangka Substitusi Tepung Terigu. Jurnal Teknologi dan Industri Pangan. Departemen Ilmu dan Teknologi Pangan, IPB, Bogor.

20. Hadiwiyoto, S. dan Soehardi, (1981). Penanganan Lepas Panen. Departemen Pendidikan dan Kebudayaan, Jakarta.

21. Hafiz, L. Ikhwan., (2008). Pengaruh Lama dan Suhu Pengeringan terhadap Mutu Tepung Pandan. Skripsi : Fakultas Pertanian, Universitas Sumatera Utara.

22. Hamsah, (2013). Karakterisasi Sifat Fisikokimia Tepung Buah Pedada (Sonneratia Caseolaris).
Skripsi : Fakultas Pertanian, Universitas Hasanuddin, Makassar.

23. Hariyadi, P. dan Aini, Nur. (2015). Dasar-dasar Penanganan Fasca Panen Buah dan Sayur. Alfabeta, Bandung.

24. Hidayat, Beni., Ahza B. Adil., dan Sugiyono. (2007). Karakterisasi Tepung Ubi Jalar (Ipomoea batatas L.) Varietas Shiroyutaka serta Kajian Potensi Penggunaan sebagai Sumber Pangan Karbohidrat Alternatif. Jurnal Teknologi dan Industri Pangan Vol. XVIII No. 1. Fakultas Teknologi Pertanian, IPB, Bogor.

25. Imanningsih, Nelis., (2012). Profil Gelatinisasi Beberapa Formulasi Tepung-Tepungan Untuk Pendugaan Sifat Pemasakan. Penel Gizi Makan 2012, 35 (1): 13-22.

26. Jading, dkk., (2011). Karakteristik Fisikokimia Pati Sagu Hasil Pengeringan secara Fluidisasi Menggunakan Alat Pengering Cross Flow Fluidized Bed Bertenaga Surya dan Biomassa Reaktor. Jurnal Pangan 13 (3): 155-164.

27. Julianti, E. (2011). Pengaruh tingkat kematangan dan suhu penyimpanan terhadap mutu buah terung belanda (Cyphomandra betacea). J. Hortikultura Indonesia 2(1).

28. Kainuma. K, Odat T, dan Cuzuki S. 1967. Study of starch Phosphates Monoester. J. Technol, Soc. Starch 14: 24-28.

29. Karim, O. Yani., (2016). Kadar Air dalam Bahan Pangan. Retrieved September 25, 2017 from : yanialkarim.blogspot.com.

30. Karsinah dan Rebin, (2013). Buah Tropika yang Berpotensi Sebagai Sumber Pangan Alternatif. Balai Penelitian Tanaman Buah Tropika, Solok, Sumatera Barat.

31. Kartono, Hendry. (2015). Penentuan Kadar Air dan Kadar Abu. Retrieved Agustus 27, 2017 from: hendry.blogspot.co.id/2015/06/penentuan-kadarair-dan-kadar-abu.html/

32. [KBBI] Kamus Besar Bahasa Indonesia versi Online. Matang. Retrieved Mei 23, 2017 from : http://kbbi.web.id/matang

33. [KBBI] Kamus Besar Bahasa Indonesia versi Online. Mengkal. Retrieved Mei 23, 2017 from : http://kbbi.web.id/mengkal

34. Komalasari, Sri., (2015). Pengaruh Perbandingan Air Rendaman dengan Kacang Koro Pedang Menggunakan Metode Sirkulasi Berpengaduk terhadap Kadar Sianida dan Kadar Protein Tepung Kacang Koro Pedang (Canavalia ensiformis). Skripsi : Fakultas Teknik, Universitas Pasundan, Bandung.

35. Kusmawati, dkk. (2000). Dasar-Dasar Pengolahan Hasil Pertanian I. Central Grafika. Jakarta.

36. Kuspito, Djoko., (2011). Sawo. Retrieved Mei 03, 2017, from Aneka Buah-buahan : http://anekabuah-buahan.blogspot.co.id/2011/05/sawo.html 
37. Kusumawati, D. Desti, Amanto S. Bambang dan Muhamad A.R. Dimas. (2012). Pengaruh Perlakuan Pendahuluan Dan Suhu Pengeringan Terhadap Sifat Fisik, Kimia, Dan Sensori Tepung Biji Nangka (Artocarpus heterophyllus). Jurnal Teknosains Pangan Vol 1 No 1, Jurusan Ilmu dan Teknologi Pangan, Universitas Sebelas Maret, Surakarta.

38. Li, J.Y. (2001). Relationship Between Thermal, Rheological Characteristics, And Swelling Power For Various Starches. J. Food Engineering Vol.50 : 141-148

39. Maharani, dkk., (2015). Metabolisme Senyawa Polisakarida. Akademisi Farmasi Saraswati, Denpasar.

40. Muchtadi, Tien., M. Sugiyono dan Ayustaningwarno Fitriyono. (2013). Ilmu Pengetahuan Bahan Pangan. Alfabeta. Bandung.

41. Natalia, (2014). Sawo Mentega. Retrieved Mei 03, 2017:https://leliisriani94.wordpress.com/category/j enis-jenis/jns-sawo-mentega/.

42. Novita, T. (2000). Peran Fisiologi Poliamin dan Etilen pada Proses Pemasakan Buah Pepaya Solo (Caricapepaya L.). Tesis. Institut Pertanian Bogor. Bogor.

43. Nurba, D., (2008). Analisis Distribusi Suhu, Aliran Udara, RH dan Kadar Air. Retrieved October 04, 2017 from : repository.ipb.ac.id.

44. Nurhasari, (2011). Pengaruh Formulasi Mentega terhadap Mutu Cookies. Laporan Praktikum : Teknologi Pangan, Fakultas Teknologi Industri Pertanian, Universitas Sahid Jakarta. Retrieved Mei 17, 2017 from Teknologi Pangan : http://elfintanurhastari.blogspot.co.id/2011/08/pengola hanbiskuit.html.

45. Pantastico, Er. B., (1997). Fisiologi Pasca Panen. Universitas Gadjah Mada Press, Yogyakarta.

46. Purwandari, U., Supriyanto dan Burhan. (2012). Sifat Fisika, Kimia, dan Tekstural Beberapa Tepung Non-Konvensional dan Karakteristik Roti Tawar yang Dihasilkan. Jurnal : Jurusan Teknologi Industri Pertanian, Universitas Trunojoyo Madura, Madura.

47. Primarasa, (2004). Kue Kering. Gaya Favorit Press, Jakarta.

48. Radiena, Mozes S.Y., (2016). Umur Optimum Panen Pisang Kepok (Musa paradisiaca, L) Terhadap Mutu Tepung Pisang. Balai Riset dan Standardisasi Industri, Ambon.

49. Rauf, Rusdin., dan Sarbini, Dwi. (2015). Daya Serap Air sebagai Acuan Menentukan Volume Air dalam Pembuatan Adonan Roti dari Campuran Terigu dan Tepung Singkong. Agritech, Vol. 35, No. 3, Fakultas Ilmu Kesehatan, Universitas Muhammadiyah Surakarta, Surakarta.

50. Rizky, (2012). Buah Alkesah. Retrieved Mei 03, 2017, from Rizumablog: http://www.rizumablog.com/2012/ buahalkesah.htm.

51. Sandria, Adi. (2015). Pengamatan Tingkat Pengaruh Kematangan. Retrieved Mei 31, 2017 from Agronomiunhas

http://agronomiunhas.blogspot. co.id/2015/03/pengamatan-tingkat-pengaruhkematangan.html?m=1.

52. Soekarto, (2006). Penilaian Organoleptik. Bharatara Karya Aksara, Jakarta.

53. Suarni, (2009). Prospek Pemanfaatan Tepung Jagung untuk Kue Kering (Cookies). Jurnal Litbang Pertanian, 28(2), 2009.

54. Suarni, (2012). Struktur dan Komposisi Biji dan Nutrisi Gandum. Balai Penelitian Tanaman Serealia. Retrieved September 15, 2017 from : balitsereal.litbang.pertanian.go.id

55. Sudarmadji, (2010). Analisa Bahan Makanan dan Pertanian. Penerbit : Liberty Yogyakarta.

56. Suprapti, (2005). Selai dan Cake. Yogyakarta. Penerbit: Kanisius.

57. Suriani, A.I., (2008). Mempelajari Pengaruh Pemanasan dan Pendinginan Berulang terhadap Karakteristik Sifat Fisik dan Fungsional Pati Garut (Marantha Arundinacea) Termodifikasi (Skripsi). Insitut Pertanian Bogor, Bogor.

58. Trisnawati, W., Suter K., Suastika K., dan Putra K. Nengah., (2014). Pengaruh Metode Pengeringan Terhadap Kandungan Antioksidan, Serat Pangan dan Komposisi Gizi Tepung Labu Kuning. Jurnal Aplikasi Teknologi Pangan, Ilmu dan Teknologi Pangan, Fakultas Teknologi Pertanian, Universitas Udayana, Bali.

59. Utami, (2010). Modifikasi Pati Ganyong Dengan Teknik Heat Moisture Treatment (HMT) Dan Aplikasinya Dalam Pembuatan Sohun Dengan Penambahan Hidrokoloid. Bogor. IPB

60. Verheij, EWM., dan Coronel, RE. (1997). Buahbuahan yang dapat dimakan, Proses, Sumberdaya Nabati Asia Tenggara 2. Gramedia Pustaka Utama. Jakarta.

61. Warta, (2015). Alkesa / Sawo Mentega. Retrieved Mei 03, 2017 http://www.wartatani.com/2015/07/alkesa-sawomentega.html

62. Wibowo, Djony. 2012. Uji Coba Pembuatan Cookies Dengan Tepung Kulit Telur Ayam Sebagai Pengganti Tepung Terigu. Publisher: Binus University.

63. Wijaya, Hendra. (2010). Kajian Teknis Standar Nasional Indonesia Biskuit SNI 01- 2973-1992. Bogor : Balai Besar Industri Argo Kementrian Perindustrian

64. Wikipedia, (2017). Pouteria campechiana. Retrieved Mei 05, 2017 from Wikipedia.org : https://en.wikipedia.org/wiki/Pouteria_campechian a. 
65. Winarno, (2008). Kimia Pangan dan Gizi. PT Gramedia Pustaka, Jakarta.

66. Yuliasih, dkk., (2007). Pengaruh Proses Fraksinasi Pati Sagu Terhadap Karakteristik Fraksi Amilosanya. Jurnal Teknologi Industri Pertanian 17 (1): 29-36. 